\title{
Analysis of RFLPs and DNA deletions in the Chinese Duchenne muscular dystrophy gene
}

\author{
Yi-tao Zeng, Mei-jue Chen, Zhao-rui Ren, Xiao-kun Qiu, Shu-zhen Huang
}

\begin{abstract}
Sixty-nine unrelated Chinese DMD patients were studied with a series of genomic and CDNA probes. Analysis of 13 polymorphic sites showed that pERT87-1, 87-8, 87-15, and $X J$ probes gave favourable allele frequencies in the Chinese population, and nearly $90 \%$ of the DMD families in this study were informative for prenatal diagnosis and carrier detection using these four polymorphic markers. Nine out of 69 (13\%) were also found to have gene deletions using a panel of genomic probes. However, when using cDNA probes, deletions were found in $56.5 \%$ of the patients. The deletions were concentrated in the areas of probes 7 and 8 , giving a proportion of about $80 \%$ of all deleted patients in this study. All these results provide valuable information for planning prenatal diagnosis programmes for DMD in China.
\end{abstract}

Duchenne muscular dystrophy (DMD) is one of the most common and severe $\mathrm{X}$ linked diseases with an incidence of approximately 1 in 3500 newborn males. ${ }^{1}$ Affected boys are normally wheelchair bound before 13 years of age and die in their late teens. Cytogenetic observations of a few females affected by the disease who all had a balanced X;autosome translocation, ${ }^{2-4}$ together with modern molecular technology, led to the localisation of the DMD gene to Xp21.5

The discovery of a number of polymorphic DNA markers which lie within, or very close to, the DMD locus itself have made more accurate carrier detection and prenatal diagnosis possible by the use of restriction fragment length polymorphisms (RFLPs). ${ }^{6-11}$ Recently, molecular investigations of a large number of DMD cases have also disclosed that DNA deletions appear to be the commonest gene defect leading to DMD. About $10 \%$ of DMD patients have DNA

Shanghai Institute of Medical Genetics, Shanghai Children's Hospital, 380 Kang Ding Road, Shanghai 200040, People's Republic of China.

Y-T Zeng, M-J Chen, Z-R Ren, X-K Qiu, S-Z Huang Correspondence to Dr Zeng.

Received for publication 8 July 1990.

Accepted for publication 1 August 1990. deletions detected with genomic probes from the DMD region. ${ }^{12-16}$ When cDNA probes have been used, the frequency of deletions has risen to more than $50 \% .7-20$

This paper reports our analysis of DNA from Chinese DMD patients using a panel of genomic and cDNA probes in the DMD gene, and the examination of RFLPs and DNA deletions at the DMD locus in Chinese.

\section{Materials and methods \\ SUBJECTS \\ One hundred normal Chinese subjects and 69 unrelated Chinese DMD patients were included in this study. All the patients had typical symptoms of DMD. Besides the clinical findings, the diagnosis was also based on a family history of DMD, significantly raised serum creatine kinase (CK) activity, pseudo- hypertrophy, hypertrophy of the calf muscles, and electromyography or muscle biopsy.}

\section{DNA ANALYSIS}

Genomic DNA was extracted from peripheral leucocytes according to the protocol of our laboratory. ${ }^{21}$ DNA was digested with restriction enzymes according to the manufacturer's instructions. The digested fragments were run on $0.9 \%$ agarose gels (Sigma), blotted onto nitrocellulose membranes. (Schleicher and Schuell) according to standard procedures, ${ }^{22}$ hybridised with $\left(\alpha-{ }^{32} \mathrm{P}\right) \mathrm{dCTP}$ (ICN) labelled DNA probes, and autoradiographed.

\section{PROBES}

Genomic probes pERT87-1, 87-8, 87-15, 87-30, and JBir were kind gifts from Dr Kunkel (Boston). XJ probes were kindly given by Dr Worton (Toronto). They are usefully polymorphic with several different restriction enzymes (Boehringer Mannheim): pERT87-1 with $B s t$ NI and $X m n I$, pERT87-8 with BstXI and TaqI, pERT87-15 with BamHI, TaqI, and

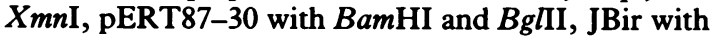
BamHI, XJ2.3 with TaqI, XJ1.1 with TaqI, and $\mathrm{XJ} 1.2$ with $B c l$. Altogether 13 polymorphic sites in the DMD locus were analysed. 
Table 1 Polymorphic DNA markers at the DMD locus in Chinese.

\begin{tabular}{|c|c|c|c|c|c|c|}
\hline \multirow[b]{2}{*}{ Probe } & \multirow{2}{*}{$\begin{array}{c}\text { Restriction } \\
\text { enzyme }\end{array}$} & \multirow{2}{*}{$\begin{array}{l}\text { Fragment } \\
\text { length (kb) }\end{array}$} & \multicolumn{2}{|c|}{ Normal subject } & \multicolumn{2}{|c|}{ DMD patient } \\
\hline & & & No & Frequency & No* & Frequency \\
\hline $\begin{array}{l}\text { JBir } \\
87-30\end{array}$ & $\begin{array}{l}\text { BamHI } \\
\text { BamHI } \\
\text { BglII }\end{array}$ & $\begin{array}{l}21 / 16,5 \\
27 / 8 \\
30 / 7 \cdot 7\end{array}$ & $\begin{array}{c}67 / 100 \\
0 / 87 \\
124 / 16\end{array}$ & $\begin{array}{l}0.60 \\
1.00 \\
0.11\end{array}$ & $\begin{array}{c}15 / 20(3) \\
1 / 36 \text { (3) } \\
30 / 7\end{array}$ & $\begin{array}{l}0.57 \\
0.97 \\
0.19\end{array}$ \\
\hline $87-15$ & $\begin{array}{l}\text { BamI HI } \\
\text { TaqI } \\
\text { XmnI }\end{array}$ & $\begin{array}{l}9 \cdot 4 / 7 \cdot 1,2 \cdot 3 \\
3 \cdot 3 / 3 \cdot 1 \\
2 \cdot 8 / 1 \cdot 6,1 \cdot 2\end{array}$ & $\begin{array}{l}32 / 71 \\
25 / 96 \\
93 / 73\end{array}$ & $\begin{array}{l}0.69 \\
0.79 \\
0.44\end{array}$ & $\begin{array}{r}16 / 28 \text { (4) } \\
3 / 37 \text { (3) } \\
30 / 10 \text { (3) }\end{array}$ & $\begin{array}{l}0.64 \\
0.93 \\
0.25\end{array}$ \\
\hline $87-8$ & $\begin{array}{l}\text { BstXI } \\
\text { TaqI }\end{array}$ & $\begin{array}{l}4 \cdot 4 / 2 \cdot 2 \\
3 \cdot 8 / 2 \cdot 7, \quad 1 \cdot 1\end{array}$ & $\begin{array}{l}51 / 106 \\
74 / 37\end{array}$ & $\begin{array}{l}0.68 \\
0.33\end{array}$ & $\begin{array}{r}7 / 29(3) \\
24 / 10(5)\end{array}$ & $\begin{array}{l}0.81 \\
0.29\end{array}$ \\
\hline $87-1$ & BstNI & $\begin{array}{l}3 \cdot 1 / 2 \cdot 4 \\
8 \cdot 7 / 7 \cdot 5\end{array}$ & $\begin{array}{l}63 / 59 \\
67 / 76\end{array}$ & $\begin{array}{l}0.48 \\
0.53\end{array}$ & $16 / 13$ (3) & $\begin{array}{l}0.45 \\
0.53\end{array}$ \\
\hline $\begin{array}{l}X J 2.3 \\
X J 1.1 \\
X J 1.2\end{array}$ & $\begin{array}{l}\text { TaqI } \\
\text { TaqI } \\
\text { BcII }\end{array}$ & $\begin{array}{l}7 \cdot 8 / 6 \cdot 4 \\
3 \cdot 8 / 3 \cdot 1 \\
2 \cdot 0 / 1 \cdot 6\end{array}$ & $\begin{array}{l}48 / 86 \\
33 / 107 \\
99 / 21\end{array}$ & $\begin{array}{l}0.64 \\
0.76 \\
0.18\end{array}$ & $\begin{array}{l}15 / 24(3) \\
10 / 28 \text { (2) } \\
28 / 7 \quad(1)\end{array}$ & $\begin{array}{l}0.62 \\
0.74 \\
0.20\end{array}$ \\
\hline
\end{tabular}

*The values in parentheses are numbers of $\mathrm{X}$ chromosomes with DNA deletion.

DMD cDNA probes $1-2 a, 2 b-3,4-5 a, 5 b-7,8$, and 9-14 were obtained from the American Type Culture Collection. DNA deletions were detected by digesting the DNA samples with HindIII using the above cDNA fragments.

\section{Results}

The 13 RFLP sites examined in this study were all within Xp21 and the DMD locus. The alleles and frequencies of each polymorphic marker in the Chinese are presented in table 1 . The results showed that there was no significant difference between the frequency of each RFLP in the normal X chromosomes and in the DMD $\mathrm{X}$ chromosomes. If the present Chinese data are compared with those of western populations, ${ }^{9102324}$ small but significant differences appear; no allelic heterozygosity could be shown, particularly at the pERT87-30/BamHI site.

Molecular deletions in the Chinese DMD gene were investigated using both a panel of genomic probes and DMD cDNA. Among the 69 patients detected with genomic probes, nine were found to have gene deletions (13\%). Of the nine, seven were deleted for

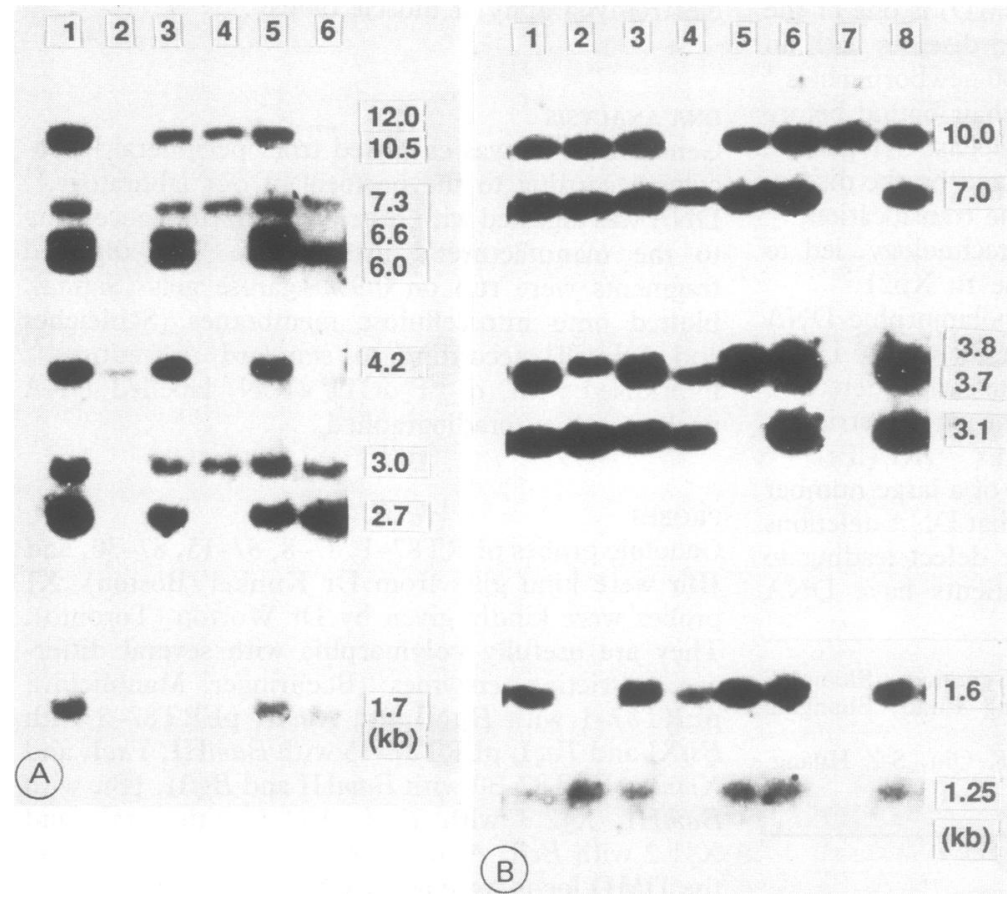

HindIII digested DNA probed with cDNA $2 b-3(A)$ and $8(B)$. (A) Lanes 2, 3, 4, and 6 show deletions. (B) Lanes 2, 4, 5, and 7 show deletions. 
the pERT87 series and two were each deleted for JBir or XJ2.3 alone. For cDNA analysis, 46 individual DMD samples were available for the series of cDNA (1-2a, 2b-3, 4-5a, 5b-7, 8, and 9-14) probe detection; 26 patients $(56.5 \%)$ had molecular deletions of one or several of the exon containing HindIII fragments (figure). The number of patients tested with each cDNA probe and the frequency and extent of the deletions are shown in tables 2 and 3. The majority of the deletions were found with probe 8 (19 out of 26 , $73 \%$ ), with a significant proportion of these (10 out of $19,52 \%$ ) extending into the distal segment of cDNA probe $5 b-7$. However, only a small proportion of deletions were detected with cDNA probes 1-2a (three out of 26, 11.5\%) and 9-14 (three out of 26, $11 \cdot 5 \%$ ). All the molecular deletions found with genomic probes were confirmed by cDNA probes.

\section{Discussion}

In this study, we used eight DNA probes to analyse

Table 2 Frequency of deletions detected with each cDNA probe.

\begin{tabular}{lccc}
\hline Probe & No tested & $\begin{array}{c}\text { Deletions } \\
\text { detected }\end{array}$ & $\begin{array}{c}\text { Frequency } \\
(\%)\end{array}$ \\
\hline $1-2 \mathrm{a}$ & 40 & 3 & $7 \cdot 5$ \\
$2 \mathrm{~b}-3$ & 40 & 6 & $15 \cdot 0$ \\
$4-5 \mathrm{a}$ & 42 & 5 & $11 \cdot 9$ \\
$5 \mathrm{~b}-7$ & 46 & 13 & $28 \cdot 2$ \\
8 & 46 & 19 & $41 \cdot 3$ \\
$9-14$ & 46 & 3 & $6 \cdot 5$ \\
\hline
\end{tabular}

13 RFLPs in the Chinese DMD locus. Almost all the polymorphic markers except pERT87-30/BamHI were useful for prenatal diagnosis and carrier detection of DMD by linkage analysis in the Chinese population. As shown in the RFLP data listed in table 1, we prefer to use four markers (pERT87-1/XmnI, 87-8/TaqI, 87-15/BamHI, and XJ2.3/TaqI), which have favourable allele frequencies, in DMD family analysis. Among the 39 Chinese DMD families who requested prenatal diagnosis, nearly $90 \%$ were informative using these four markers, and 24 obligate carrier mothers all showed heterozygosity for the above polymorphic sites. There was no evidence to indicate that recombination occurred in these families. Although our study has shown gene deletion in approximately $50 \%$ of Chinese DMD patients, and prenatal diagnosis can be performed by direct detection of deletions using cDNA probes in these cases, RFLP linkage analysis is still very useful for prenatal diagnosis in the rest of the DMD families. So far 26 fetuses at risk for DMD have been prenatally diagnosed by RFLP linkage analysis. 2526

At present, DNA deletions in DMD can be examined using both genomic and cDNA probes. When genomic markers were used, the frequency of the deletions varied depending on the number of markers and on the methods used. ${ }^{12-16}$ Of the 69 DMD patients included in this study, deletions were found in nine (13\%) unrelated patients. When 46 patients who were available for subsequent analysis were tested with cDNA probes, deletions were found in 26 patients $(56.5 \%)$, which is in agreement with previously published reports using the same cDNA

Table 3 Deletions in the DMD patients relative to exon containing HindIII fragments detected with cDNA probes.

\begin{tabular}{|c|c|c|c|c|c|c|}
\hline Probe & $1-2 a$ & $2 b-3$ & 4-5a & $5 b-7$ & 8 & $9-14$ \\
\hline Size (kb) & \multicolumn{6}{|c|}{ ن் } \\
\hline $\begin{array}{l}\text { Case 7 } \\
\text { Case } 51 \\
\text { Case } 24 \\
\text { Case } 12 \\
\text { Case 44 } \\
\text { Case 21 } \\
\text { Case } 34 \\
\text { Case } 56 \\
\text { Case } 46 \\
\text { Case 60 } \\
\text { Case } 3 \\
\text { Case 6 } \\
\text { Case } 58 \\
\text { Case } 53 \\
\text { Case 62 } \\
\text { Case 26 } \\
\text { Case 44 } \\
\text { Case 40 } \\
\text { Case } 2 \\
\text { Case 47 } \\
\text { Case 28 } \\
\text { Case } 10\end{array}$ & . & & & & & \\
\hline
\end{tabular}

The patients who were subjected to the whole series of cDNA detection are presented. 
probes. ${ }^{17-20} 27-29$ The concentration of deletions in the area of probes 8 and 7 in the Chinese DMD patients is also similar to that reported by others. ${ }^{27-29}$ However, the clinical severity of deletion cases was no different from that of the non-deleted patients. By means of the cDNA probes, prenatal diagnosis of male fetuses in all deletion families can be based on the presence or absence of the bands that are deleted in the affected males. Recently, the application of multiple DNA amplification with PCR to the molecular diagnosis of $\mathrm{DMD}{ }^{30}{ }^{31}$ has greatly simplified the analytical procedures and enhanced our ability to detect deletions, which assists in prenatal diagnosis in DMD families.

This study was supported by China National 863 Research Grant. The authors thank Misses Mei-lan Zhang and Min Shen at Shanghai Institute of Medical Genetics for their excellent technical assistance. We are also grateful to Miss Hai-lan Zhang for the preparation of this manuscript.

1 Emery AEH. Differential diagnosis. In: Emery AEH, ed. Duchenne muscular dystrophy. Oxford: Oxford University Press, 1987:71-91.

2 Greenstein RM, Reardon MP, Chan TS. An X autosome translocation in a girl with Duchenne muscular dystrophy (DMD): evidence of DMD gene localisation. Pediatr Res 1977;11:457.

3 Lindenbaum RH, Clarke G, Patel C, Moncrieff $M$, Hughes JT. Muscular dystrophy in an $\mathrm{X} ; 1$ translocation female suggests that Duchenne locus is on $\mathrm{X}$ chromosome short arm. $\mathcal{F}$ Med Genet 1979;16:389-92.

4 Zatz M, Vianna-Morgante AM, Campos P, Diament AJ. Translocation $(X ; 6)$ in a female with Duchenne muscular dystrophy: implications for the localisation of the DMD locus. 7 Med Genet 1981;18:442-7.

5 Davies KE, Pearson PL, Harper PS. Linkage analysis of two cloned DNA sequences flanking the Duchenne muscular dystrophy locus on the short arm of the human X chromosome. Nucleic Acids Res 1983;11:2303-12.

6 Bakker E, Hofker MH, Goor N, et al. Prenatal diagnosis and carrier detection of Duchenne muscular dystrophy with closely linked RFLPs. Lancet 1985;i:655-8.

7 Bakker E, Bonten EJ, deLange LF, et al. DNA probe analysis for carrier detection and prenatal diagnosis of Duchenne muscular dystrophy: a standard diagnostic procedure. F Med Genet 1986;23:573-80.

8 Darras BT, Harper JF, Francke U. Prenatal diagnosis and detection of carriers with DNA probes in Duchenne's muscular dystrophy. $N$ Engl F Med 1987;316:985-92.

9 Old JM, Davies KE. Prenatal diagnosis of Duchenne muscular dystrophy by DNA analysis. $\mathcal{F}$ Med Genet $1986 ; 23: 556-9$.

10 Lindlöf $M$, Kääriainen H, Davies KE, de la Chapelle A. Carrier detection and prenatal diagnosis in $\mathrm{X}$-linked muscular dystrophy using restriction fragment length polymorphisms. F Med Genet 1986;23:560-72.

11 Forrest SM, Smith TT, Cross GS, et al. Effective strategy for prenatal prediction of Duchenne and Becker muscular dystrophy. Lancet 1987;ii:1294-7.

12 Monaco AP, Bertelson CJ, Middlesworth W, et al. Detection of deletions spanning the Duchenne muscular dystrophy locus using tightly linked DNA segment. Nature 1985;316:842-5.

13 Kunkel LM, Hejtmancik JF, Caskey CT, et al. Analysis of deletions in DNA from patients with Becker and Duchenne muscular dystrophy. Nature 1986;322:73-7.

14 Ray PN, Belfall B, Duff C, et al. Cloning of the breakpoint of an $\mathrm{X} ; 21$ translocation associated with Duchenne muscular dystrophy. Nature 1985;318:672-5.

15 Thomas NST, Ray PN, Worton RG, Harper PS. Molecular deletion analysis in Duchenne muscular dystrophy. $7 \mathrm{Med}$ Genet 1986;23:509-15.

16 Davies KE, Smith TJ, Bundey S, et al. Mild and severe muscular dystrophy associated with deletions in Xp21 of the human X chromosome. F Med Genet 1988;25:9-13.

17 Forrest SM, Cross GS, Speer A, Gardner-Medwin D, Burn J, Davies KE. Preferential deletion of exons in Duchenne and Becker muscular dystrophy. Nature 1987;329:638-40.

18 Koening M, Hoffman EP, Bertelson CJ, Monaco AP, Feener C, Kunkel LM. Complete cloning of the Duchenne muscular dystrophy (DMD) CDNA and preliminary genomic organisation of the DMD gene in normal and affected individuals. Cell 1987;50:509-17.

19 Forrest SM, Cross GS, Flint T, Speer A, Robson KJH, Davies KE. Further studies of gene deletions that cause Duchenne and Becker muscular dystrophies. Genomics 1988;2:109-14.

20 den Dunnen JT, Bakker E, Klein Breteler EG, Pearson PL, van Ommen GJB. Direct detection of more than $50 \%$ of Duchenne muscular dystrophy mutations by field inversion gels. Nature 1987;326:640-2.

21 Zeng YT, Huang SZ. Alpha-globin gene organisation and prenatal diagnosis of alpha-thalassaemia in China. Lancet 1985;i:304-6.

22 Southern EM. Detection of specific sequences among DNA fragments separated by gel electrophoresis. f Mol Biol 1975;98: 503-17.

23 Bertelson CJ, Bartley JA, Monaco AP, Colletti-Feener C, Fishbeck K, Kunkel LM. Localisation of Xp21 meiotic exchange points in Duchenne muscular dystrophy families. $\mathcal{F}$ Med Genet 1986;23:531-7.

24 Thompson MW, Ray PN, Belfall B, et al. Linkage analysis of polymorphisms within the DNA fragment XJ cloned from the breakpoint of an X;21 translocation associated with X linked muscular dystrophy. 7 Med Genet 1986;23:548-55.

25 Zeng YT, Qiu XK, Chen MJ, et al. Restriction fragment length polymorphisms on Xp21 region of the X chromosome in normal Chinese and DMD patients. Chin Biochem f 1988;4:458-66.

26 Zeng YT, Zhang ML, Xu YJ, Shen M, Huang SZ. Prenata diagnosis of Duchenne muscular dystrophy by RFLPs linkage analysis. Natl f Med China 1988;68:565-8.

27 Lindlöf $\mathbf{M}$, Kiuru A, Kääriainen $\mathbf{H}$, et al. Gene deletions in Xlinked muscular dystrophy. Am f Hum Genet 1989;44:496-503.

28 Passos-Bueno MR, Rapaport D, Love D, et al. Screening of deletions in the dystrophin gene with the CDNA probes Cf23a, Cf56a, and Cf115. I Med Genet 1990;27:145-50.

29 Cooke A, Lanyon WG, Wilcox DE, et al. Analysis of Scottish Duchenne muscular dystrophy families with dystrophin cDNA probes. F Med Genet 1990;27:292-7.

30 Chamberlain JS, Gibbs RA, Ranier JE, Nguyen PN, Caskey CT Deletion screening of the Duchenne muscular dystrophy locus via multiple DNA amplification. Nucleic Acids Res 1988;16: 11141-55.

31 Gibbs RA, Chamberlain JS, Caskey CT. Diagnosis of new mutation diseases using the polymerase chain reaction. In: Erlich HA, ed. PCR technology, principles and applications for DNA amplification. New York: Stockton Press, 1989:171-91. 